\title{
Shale gas from Amazonas Basin: a new energy source for mining industry instead of hydroelectric power
}

\author{
${ }^{1}$ Gabriel Lobato Cardoso, ${ }^{2}$ Estanislau Luczynski. ${ }^{1,2}$ Federal University of Pará; Nucleus of Research in Oil and Natural Gas
} in the Amazon

Copyright 2019, SBGf - Sociedade Brasileira de Geofísica

This paper was prepared for presentation during the $16^{\text {th }}$ International Congress of the Brazilian Geophysical Society held in Rio de Janeiro, Brazil, 19-22 August 2019.

Contents of this paper were reviewed by the Technical Committee of the $16^{\text {th }}$ International Congress of the Brazilian Geophysical Society and do not necessarily represent any position of the SBGf, its officers or members. Electronic reproduction or represent any position of the SBGf, its officers or members. Electronic reproduction or
storage of any part of this paper for commercial purposes without the written consent storage of any part of this paper for commercial
of the Brazilian Geophysical Society is prohibited.

\begin{abstract}
We discussed the possibility of shale gas exploration in the Amazonas Basin for the replacement of hydroelectric energy in mining activities in the state of Pará, based on the potential of this basin for generation and storage from data of geophysical profiles, total organic carbon content (TOC) and curves of hydrogen index (HI). We present a suggestion for a gas pipeline to connect the fields of shale gas explotation to the mining systems of the Carajás Complex.
\end{abstract}

\section{Introduction}

Since the first Oil Shock, petroleum dependent countries increased their researches for new energy sources, including natural gas (NG). They were aiming at environmentally and sustainable option for industry (DOS SANTOS, 2000). In USA, from 1980 to 2010, some nonconventional reservoirs of natural gas (NCNG) were exploited, especially the shale gas of Barnett Formation at Fort Worth Basin, Texas and Marcellus Shale at Appalachian Basin, New York (MONTGOMERY et. al, 2009; BASTO, 2014).

Following other countries, Brazil choose natural gas as an option for energy generation in industrial, commercial and household sectors (SANTOS, 2000), which increased the NG and NCNG reserves. In 2013, the first bidding (oil and gas round) for non-conventional gas singled out Paraná, Recôncavo and Amazonas basins as possible areas for shale gas. However, a Governmental Act (Environmental Moratorium) prohibited any kind of research or explotation in NCNG (CARDOSO, FURTADO, LUCZYNSKI, 2018). Among the already mentioned basins, Amazonas has the better total organic carbon (TOC) grade. This one occurs in Barreirinha Formation, which is the main generation zone of a conventional petroleum system and most promising play for non-conventional gas. Barrerinha Formation distributes itself between Amazonas and Pará states as identified by PETROBRAS studies from 1950 to 1960 (OLIVEIRA, 2015).

Although the NG potential of Amazonas basin, there is a lack of studies related to exploration and production of NCNG. Therefore, this paper presents a study on viability of shale gas from Amazonas basin aimed at mining industry of Pará state, which is hydroelectric intensive. Such energy model generates various social and environmental impacts. This paper also discusses the possible implementation of gas pipelines and their socioeconomic effects for local economy.

\section{Shale Gas}

Shale reservoirs of natural gas have permeability > $0.001 \mathrm{mD} \leq 0.0001 \mathrm{mD}$, while conventional reservoirs are in $>10 \leq 100 \mathrm{mD}$ range (KING, 2012). Sometimes, the $N G$ is adsorbed in porous of siliciclastic lenses (sweet spots) thus being a non-conventional gas system, which differs widely of structural or stratigraphic traps (LUCZYNSKI, 2014).

Owing to such considerations, the geophysical prospection for shale gas has its particularities. For example, data acquisition by multi-azimuthal seismic with 3 components and vertical seismic profiling (VSP) (MONTEIRO, 2013). Concerning to exploration, shale gas industry has a more invasive technology the hydraulic fracturing (fracking) (MARTINS \& FUSER, 2016), which can be monitored by microseismic (passive source) and analysis of gravimetric data of induced fractures (CARDOSO \& LUCZYNSKI, 2018; FULTON, 2004).

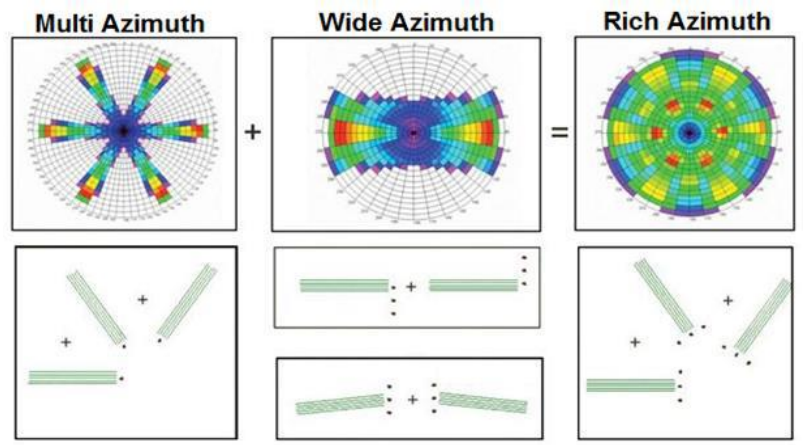

Figure 1: seismic acquisition geometries used in the exploitation of shale gas and the positioning of sources and geophones. Adapted from BACHRACH et al., 2013.

Because of this, the Environmental Moratorium nor authorized shale gas exploration in Brazil from 2013 to 2015. The Act does banned even essays in situ of fracking in the 11 blocks singled out for non-conventional gas of $13^{\text {th }}$ oil round (CARDOSO, FURTADO, LUCZYNSKI, 2018). However, nowadays there is a resumption of studies aiming at shale gas placing in the 
Brazilian Energy Matrix, yet bringing some new laws for operational security and controlling.

\section{Amazonas Basin}

It is located at North region of Brazil with $620,000 \mathrm{~km}^{2}$ between Pará and Amazonas states and ENE-WSW direction (BRASIL, 2015).
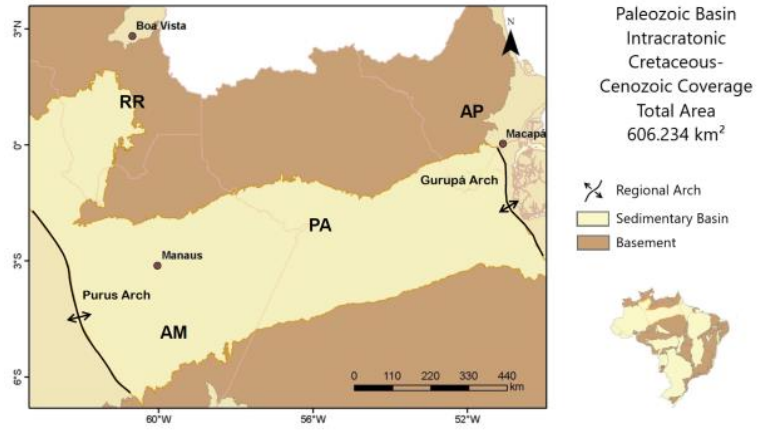

Figure 2: location, delimitation and geology of the Amazonas Basin. Modified from FERREIRA, BASTOS, LUPARELLI, 2015.

\section{a. Petroleum Systems}

According to KLEMME (1980), which typifies basins and their potential for hydrocarbon generation, Amazonas basin is Type I - Craton Interior Basins (EIRAS, 2011), however the most promising prospects for shale gas are Type III - Continental Rifted Basins.

The conventional petroleum systems are Devonian and Silurian sequences with Neocarboniferous, Middle Carboniferous and Neodevonian reservoirs sealed by evaporites, limestones, diamictites and shales. All of them with similar dating (BRASIL, 2015). There are three conventional petroleum systems: Barreirinha-Nova Olinda, Barreirinha-Monte Alegre and Barreirinha-Curiri (BRASIL, 2015) with structural (anticlines derived from reverse faults) and stratigraphic (unconformity) traps (PETRONILHO, 2014). Thermal maturation is due burial in the central part of basin and igneous intrusions near the source rocks (Penatecaua diabase) (DIGNART \& VIEIRA, 2008).

The bottom shales of Barreirinha Formation and Pitinga are the main generation zone of basin in accordance with TOC values and pyrolysis curves for both of them (DIGNART \& VIEIRA, 2008; GONZAGA et al., 2000). Barreirinha Formation deserves more attention, because it shows some high grades of organic matter and radioactivity in Abacaxis Member. It has laminated and fissile black shales with fine sandstones and siltstones inserted within and having a width varying from $30 \mathrm{~m}-40 \mathrm{~m}$ (platform) to $150 \mathrm{~m}-160 \mathrm{~m}$ (depocenter) (CUNHA et al., 2007; OLIVEIRA, 2015). In Amazonas basin, the focus for shale gas exploration is Barreirinha Formation and its fine lenses of sandstone with sweet spots. They have a lateral distribution along the formation, as well as fractures and faults that can help in gas adsorption. Curiri Formation, which is stratigraphically above Barreirinha has also possibilities for NCNG.

\section{b. Shale Gas and the Potential of Amazonas Basin}

Data analysis show the importance of Abacaxis Member (Barreirinha) for generation and exploration of shale gas. The grades of TOC vary from $3 \%$ to $8 \%$, index of vitrinite $>1.4 \%$, the hydrogen index $(\mathrm{HI})$ vary from $100 \mathrm{mg} \mathrm{HC} / \mathrm{g}$ to $400 \mathrm{mg} \mathrm{HC} / \mathrm{g}$ of TOC, and $\mathrm{S}_{2}$ curve (pyrolysis) have numbers from $4 \mathrm{mg} \mathrm{HC} / \mathrm{g}$ to $20 \mathrm{mg} \mathrm{HC} / \mathrm{g}$ of rock. Such values indicate the presence of kerogene Type II, which is the main generator of natural gas (OLIVEIRA, 2015; CAPUTO, 1984; GONZAGA et al., 2000; NEVES, 1990).

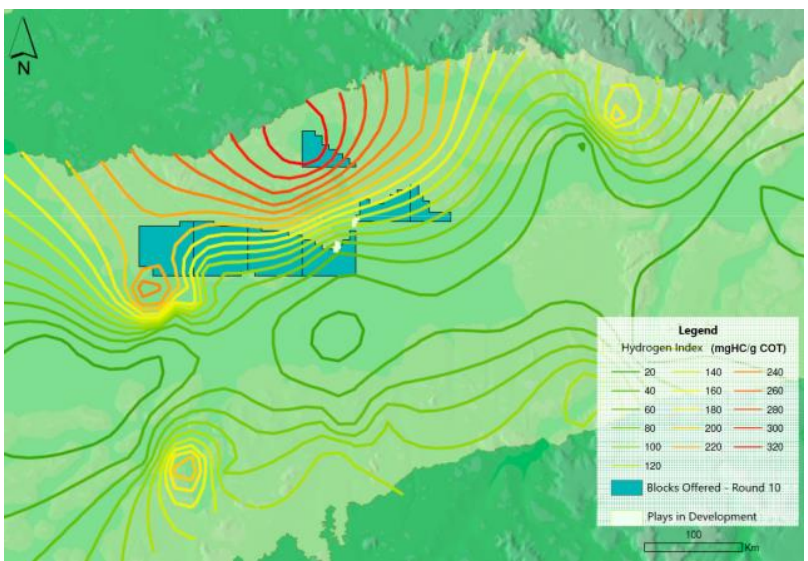

Figure 3: contour map of the hydrogen index in the Amazonas Basin, indicating a potential zone for shale gas in the depocenter at North of the basin. Modified from DIGNART \& VIEIRA, 2008.

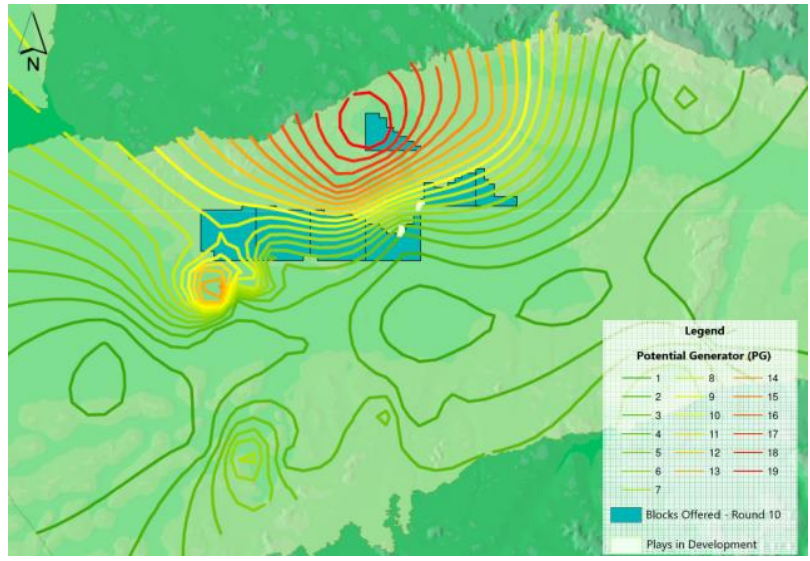

Figure 4: contour map of TOC corroborating with the hydrogen index data. Modified from DIGNART \& VIEIRA, 2008.

The interpretation of well log data by PETROBRAS show the potential for shale gas. Gamma ray curves have high values of well radioactivity in depths from $1500 \mathrm{~m}$ to $1600 \mathrm{~m}$ drilled at Abacaxis River. Some other data: resistivity, neutron porosity log, density and seismic point to an oil and natural prospect. Take into account index of vitrinite there is the possibility of shale gas at basin depocenter since thermal has the influence of dykes and diabase sills (PETRONILHO, 2014). 


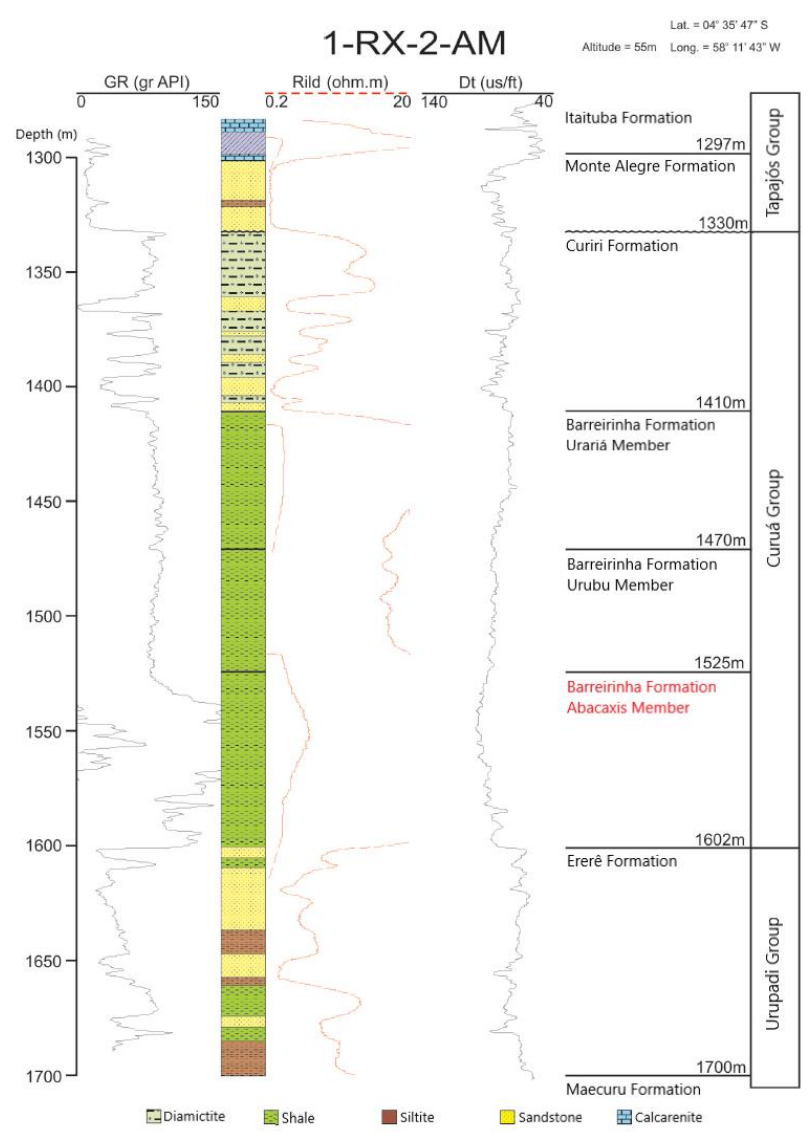

Figure 5: data from a well profile survey in the Amazonas Basin. It is worth noting the positive deflection of the gamma ray curve when reaching the Abacaxis Member of the Barreirinha Formation, indicative of potential zone for hydrocarbons. Adapted from CUNHA et al., 2007

\section{Viability of Shale Gas Exploration in Amazonas Basin}

Pará state has a steady mining industry and it is hydroelectric energy intensive. Natural gas could be a new energy option, so the hydroelectric power would supply other economic sectors like household (for example).

The first mention to NG for mining industry comes from 1980 when the Projeto Grande Carajás (PGC) started. However, at that time the options were charcoal and hydroelectric power. By 2004, new studies resumed gas supplying to Pará and its industrial sector (LUCZYNSKI, 2013). Those studies were influenced by the projects of a South American Gas Pipeline (GASUN) and Gasoducto del Sur, the last one a personal project of President Chavez. The route of both pipelines crossed the Pará territory aiming at the big energy markets of Brazilian South-Center together with Bolivia-Brazil Pipeline (GASBOL). The Pará route was nearby the mining area, thus if the project planned some gas city gates, local mining industry would receive their supply. Unfortunately, today gas supply for Pará industry is still in planning.

If a gas supply become a reality, Pará would be a steel producer instead of pig iron one and some new industries (energy intensive ones) could open their operations in
Pará. Nonetheless, the development of a shale gas industry has some constraints: a) a legal framework for shale gas is necessary. The law would prevent social and environmental impacts maybe introducing a system of penalties by payment of fees and b) the supply technology. There are some studies about supply or transportation alternatives. The first option is the pipeline, although any project like that has to deal with the problems of a big scale plant inside the Amazon rain forest and the environmental turmoil that it would create. More, to supply mining industry is necessary to choose between Natural Gas Liquid (NGL) transportation, which exempt pipelines, but it demands railway, barges or trucks suitable for NGL carry. Depending on the technology, the supply chain would have cryogenesis station or gas treatment plants.

Brazilian Government jointly with industrial sectors and natural gas supply companies have plans to interconnect all gas pipelines in one only gas ring. Therefore, natural gas from Bolivia and some Brazilian fields would supply all industrial regions or, more important, Brazil would develop its gas industry and become self-sufficient, thereby reducing its imports of $\mathrm{NG}$.

As a suggestion to supply the energy demand of the Carajás Complex through the using of natural gas, this paper proposes the continuity of the Amazonas Pipeline project from the Northwest of Pará to the connection with the projected network made up of the Pará Pipeline, Middle-North Pipeline and the Center-North Pipeline, the latter with a branch to the Carajás Complex already foreseen in the project (EPE, 2016; GASNET, 2018). Such a route would avoid the passage of a pipeline through regions of high forest density, extensively cut by rivers and would allow the insertion of Shale Gas into the gas network of the main cities of the North-Northeast axis, in addition to establishing a distribution route to the Center-East of the country and the interconnection with gas pipelines of the Southeast region, by the Central Brazil Pipeline, besides fulfilling the objective of transporting the gas to the Carajás Complex.

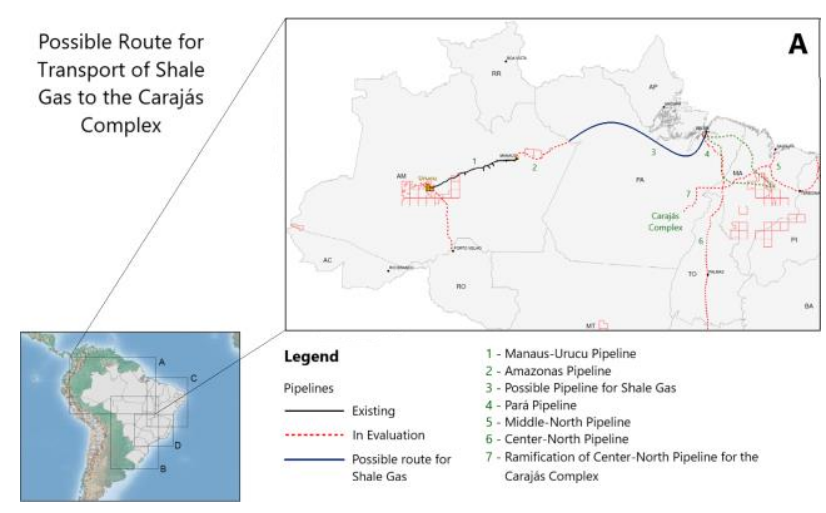

Figure 6: virtual tracing of a transport gas pipeline for shale gas flow to the benefited activities of the Carajás Complex, taking into account the pipelines projected until then. Font: EPE, 2016. Adapted by the authors. 


\section{Conclusions}

It is worth highlighting that an energy alternative for Projeto Carajás based on shale gas is a suggestion without a prior viability study in terms of economics, production and transportation or supplying. Not to mention pricing and regulation but rather energy potential to replace hydroelectric power.

Pará mining industry will get the benefits of shale gas as energy source. First, the decrease of its dependence of hydroelectric power thereby supplying some other sectors. Second, industrial processes with energy lower costs. Third, verticalisation of production with more aggregate value products, for example steel instead pig iron. Fourth, the possibility of cogeneration (NG + hydroelectricity) expanding energy supply for mining plants.

However, there is a problem to overcome transportation or supply. Pipelines or any other alternative may lead to ignition endless discussions about Amazon rain forest and social and environmental impacts. Most of them without rationality. Therefore, a legal framework is necessary before any shale gas exploration. It will protect the investors safeguard the environment.

As for the virtual layout of the pipeline, it is important to highlight that it also took place in a suggestive manner, requiring more detailed studies on its technical, logistical, economic and environmental viaibility. Such a design was thought considering a series of projects still in progress and did not take into account major physical and political obstacles. The intention of this work is to arouse interest for the regional development of the Amazon from its internal resources, respecting all its specificities.

\section{Acknowledgments}

Special thanks to Agência Nacional do Petróleo, Gás Natural e Biocombustíveis (ANP) for the data provided to the development of this paper.

\section{References}

BASTO, Jorge Manuel Portas. Problemática do Shale Gas: da Estimação de Reservas aos métodos de Desenvolvimento e Produção. 2014.

BRASIL. Agência Nacional do Petróleo, Gás Natural e Biocombustíveis. Bacia do Amazonas: sumário geológico e setores em oferta. Rio de Janeiro, 2015.

CAPUTO, Mário Vicente. Stratigraphy, tectonics, paleoclimatology and paleogeography of northern basins of Brazil. 1984. Tese de Doutorado. University of California, Santa Barbara.

CARDOSO, G. L.; FURTADO, G. R.; LUCZYNSKI, E. Moratória Ambiental sobre a exploração de gás em folhelho no Brasil: pontos positivos e negativos. In: CONGRESSO BRASILEIRO DE GEOLOGIA. 49., 2018, Rio de Janeiro. Anais do Evento. Rio de Janeiro, 2018.

CARDOSO, G. L.; LUCZYNSKI, E. Sísmica de refração para o monitoramento da exploração de gás natural na bacia do Amazonas via fraturamento hidráulico. In: SIMPÓSIO DE ESTUDOS E PESQUISAS EM CIÊNCIAS AMBIENTAIS NA AMAZÔNIA. 7., 2018, Belém. Resumo dos trabalhos. Belém, 2018.

CUNHA, P.R.C.; MELO, J.H.G.; SILVA, O.B. Bacia do Amazonas. In: Bacias Sedimentares Brasileiras - Cartas Estratigráficas: Boletim de Geociências da Petrobras, v. 15, no. 2, 2007. p 227-251.

DIGNART, A; VIEIRA, J. R. Décima Rodada de Licitações: Bacia do Amazonas. Rio de Janeiro: Agência Nacional do Petróleo, Gás Natural e Biocombustíveis, 2008.

DOS SANTOS, Edmilson Moutinho. Gás natural: estratégias para uma energia nova no Brasil. Annablume, 2002.

EIRAS, J. F. Roteiro geológico do vale do rio Tapajós, borda Sul da Bacia do Amazonas, município de Itaituba, Pará. Pará. Belém. HRT Oil/Gas. 2011. (Relatório Interno).

EMPRESA DE PESQUISA ENERGÉTICA (EPE). Infraestrutura de Gasodutos de Transporte no Brasil. Rio de Janeiro: EPE, 2016. 1 mapa, color., $1189 \mathrm{~mm}$ x 841 $\mathrm{mm}$. Escala: 1:1.000.000.

FULTON, Tom. Geophysical Needs for Barnett Exploitation. In: Barnett Shale and Other Fort Worth Basin Plays Ellison Miles Memorial Symposium. 2., 2004, Texas. Abstracts. Texas: EMGI, 2004. p. 7.

GASNET.

Disponível

em: <http://www.gasnet.com.br/gasodutos/projetados.asp>. Acesso em 15 dez. 2018.

GONZAGA, F. G.; GONÇALVES, F. T. T.; COUTINHO, I. E. C. Petroleum geology of the Amazonas Basin, Brazil: modelling of hydrocarbon generation and migration. AAPG Memoir 73, 2000. p. 159-178.

KING, G. E. SPE, Apache Corporation. 2012. Hydraulic Fracturing 101: What Every Representative, Environmentalist, Regulator, Reporter, Investor, University Researcher, Neighbor and Engineer Should Know About Estimating Frac Risk and Improving Frac Performance in Unconventional Gas and Oil Wells. In: SPE Hydraulic Fracturing Technology Conference. SPE-152596-MS.

KLEMME, H. D. Petroleum basins--classifications and characteristics. Journal of petroleum geology, v. 3, n. 2, p. 187-207, 1980.

LUCZYNSKI, Estanislau. A Oferta de Gás Natural ao Estado do Pará: uma discussão a respeito de alternativas e dos impactos socioeconômicos. 2013. 33 f. Oficina sobre Insumos Energéticos ao Pará (P\&G). Universidade Federal do Pará, Pará, 2013.

LUCZYNSKI, Estanislau. Introdução a Geologia do Petróleo. Pará: Universidade Federal do Pará, 2014. 
MARTINS, Rhodiney Vaz; FUSER, Igor. PANORAMA DO MERCADO BRASILEIRO DE GÁS NATURAL E SUA PERSPECTIVA PARA A EXPLORAÇÃO DO SHALE GAS, 2016.

MONTEIRO, G. C. Estudo de Gás em Folhelho na Formação Ponta Grossa, Bacia do Paraná. Trabalho de Graduação, Universidade Federal Fluminense, Niterói, Brasil. 2013.

MONTGOMERY, Scott L. et al. Mississippian Barnett Shale, Fort Worth basin, north-central Texas: Gas-shale play with multi-trillion cubic foot potential. AAPG bulletin, v. 89, n. 2, p. 155-175, 2005.

NEVES, C.A.O.; LIMA, M. P.; TRAVASSOS, W. A. S.; SOUZA, J. M. P.; COSTA, A. R. A.; ARANA, J.; OLIVEIRA, E. J. B. Projeto de exploração - Bacia do Amazonas. Belém: Petrobras/DENOR, 1990. Relatório Interno.

OLIVEIRA, Siana Soares de. Caracterização de reservatórios não convencionais Shale Gas na Formação Barreirinhas, Bacia do Amazonas. 2015.

PETRONILHO, CAIO ALMEIDA COSTA. SISTEMAS PETROLÍFEROS DA BACIA DO AMAZONAS E POSSIBILIDADE PARA “SHALE GAS”. 2014. 